\title{
Novel Analytical Method Development, Validation and Stability Study of Anticancer Drug Erlotinib in Tablet Dosage Form by RP-UFLC
}

\author{
Purvini K, ${ }^{1}$ Chethan IA, ${ }^{2}$ Jaishree Vaijanathappa, ${ }^{2, *}$ \\ ${ }^{1}$ Department of Pharmaceutical Analysis, Sri Adichunchanagiri College of Pharmacy, B. G. Nagara, Karnataka, INDIA. \\ ${ }^{2}$ Department of Pharmaceutical Chemistry, JSS College of Pharmacy, JSS AHER, Mysuru, Karnataka, INDIA.
}

\begin{abstract}
Present work is aimed to develop a novel, simple and accurate reverse phase-ultrafast liquid chromatographic (RP-UFLC) method for erlotinib (ELB) in tablet dosage form. The chromatogram was achieved by using Eclipse plus $\mathrm{C}_{18}$ column with methanol and water along with triethylamine (TEA $0.1 \%$ ) as mobile phase $(50: 50 \mathrm{v} / \mathrm{v}$ ) at a flow rate of $1 \mathrm{ml} / \mathrm{min}$. The tablet dosage form was assayed, validated and subjected to degradation studies. The standard ELB possessed a retention time of $5.51 \mathrm{~min}$ and the developed method was linear in the concentration range of $10-100 \mu \mathrm{g} / \mathrm{ml}$ with $r^{2} \leq 0.99$. Validation parameters have shown that the developed method was precise (\%RSD $<1$ ), accurate (recovery 98.50 to $99.52 \%$ ) and robust. In the degradation studies, no extra products were observed in thermal conditions and a degraded product was observed in negligible percentage in basic and acidic conditions.
\end{abstract}

Key words: Erlotinib, Accuracy, Precision, Robustness, Degradation study.

\section{INTRODUCTION}

As an oral drug medication ELB is used in the treatment of lung cancer, especially in non-small cell lung cancer which proliferates to other body parts. It is also used in combination with other medications such as gemcitabine (used to treat pancreatic cancer). ELB (Figure 1) is a tyrosine kinase inhibitor which acts by blocking particular proteins that enhances the growth of cancer. The specific protein blocked by ELB is epidermal growth factor receptors (EGFR). Cancer cells containing these receptors are called EGFR positive. ${ }^{1}$ Survey of literature reveals that several methods were reported for the determination of ELB. ${ }^{2-9}$ However, no methods were reported on the tablet formulation of ELB. Hence, our aim was to develop and validate a novel RP-UFLC method.

\section{MATERIALS AND METHODS}

\section{Chemicals and reagents}

ELB was purchased from Indian Chemicals, Mumbai. Erlocip tablets of Cipla Pharmaceuticals were procured from a local pharmacyoutlet.Methanol(HPLCgrade)was purchased from Rankem, Mumbai. Triethylamine (TEA, HPLC grade) was obtained from Sd Fine Chemicals Limited, Gujarat. Millipore water was obtained from Millipore system (Aquelix-5) of our laboratory. All other solvents utilized for the analysis were of AR grade.

\section{Instrumentation and chromatographic conditions}

The development and validation of the method was carried out using a HPLC from Shimadzu, equipped with LC Solutions software. Eclipse plus $\mathrm{C}_{18}$ HPLC column
Submission Date: 29-05-2020; Revision Date: 02-12-2020; Accepted Date: 13-04-2021

DOI: 10.5530/ijper.55.2s.131 Correspondence: Dr. Jaishree $\boldsymbol{V}$ Department of Pharmaceutical Chemistry, JSS College of Pharmacy, JSS AHER, Mysuru-570015, Karnataka, INDIA.

Phone no: +919480177840 Email id: vjaishree@jssuni. edu.in 


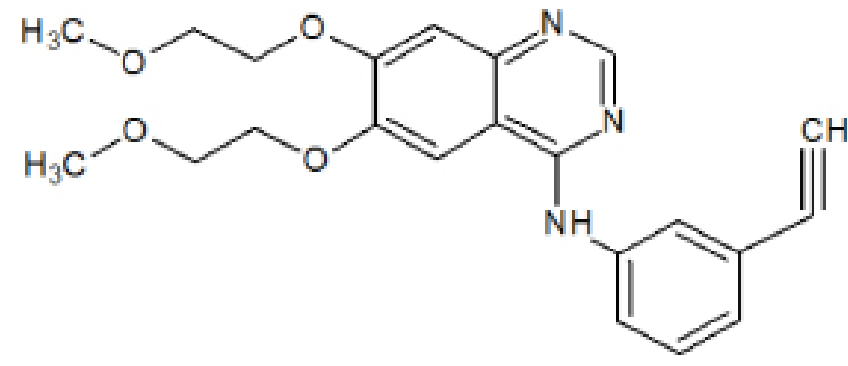

Figure 1: Erlotinib.

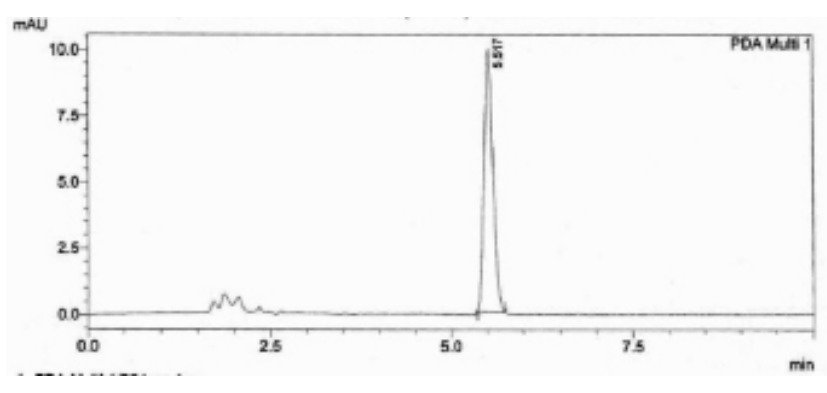

Figure 2: Chromatogram of standard erlotinib.

$(250 \times 4.6 \mathrm{~mm}$, particle size $5 \mu)$ was used to analyze the tablet formulation for the period of $10 \mathrm{~min}$.

The mobile phase consisted of methanol (A) and water with TEA $0.1 \%$ (B) previously filtered through a membrane filter of $0.45 \mu \mathrm{m}$ to ensure high levels of purity and utmost freedom from impurities. $\mathrm{pH}$ of the mobile phase was adjusted by using $\mathrm{pH}$ meter (Systronics).The mobile phase was degassed for $15 \mathrm{~min}$ and the flow rate was maintained at $1 \mathrm{ml} / \mathrm{min}$. Sonicator (GT Sonic) was used to obtain uniform mixing and degassing of the mobile phase. The temperature of the column was maintained at $37^{\circ} \mathrm{C}$. The detector wavelength was adjusted to $240 \mathrm{~nm}$. The stock solutions were prepared by accurately weighing the drug via a Digital balance (Shimadzu).

\section{Method development}

\section{Preparation of standard solution}

The active pharmaceutical ingredient ELB $(10 \mathrm{mg})$ was accurately weighed and transferred to $100 \mathrm{ml}$ volumetric flask. Methanol $(50 \mathrm{ml})$ was added to the flask and sonicated for $5 \mathrm{~min}$ to aid dissolution and the volume was made up to $100 \mathrm{ml}$ for achieving $100 \mu \mathrm{g} / \mathrm{ml}$ concentrations. Further dilutions were made to obtain 10 , $20,40,60,80$ and $100 \mu \mathrm{g} / \mathrm{ml}$ concentrations.Demonstration of the chromatogram using optimal conditions is portrayed in Figure 2.

\section{Evaluation of system suitability}

The parameters for system suitability such as column efficiency, plate count and tailing factor were recorded.
System suitability was determined by injecting six replicates of the standard solution $(10 \mu \mathrm{g} / \mathrm{ml})$.

\section{Analysis of Erlotinib in tablet dosage form}

A statistically significant number (20) of Erlocip tablets (label claim of $150 \mathrm{mg}$ ) were weighed and crushed to form a powder. This powder form of the drug, equivalent to $10 \mathrm{mg}$ ELB was accurately weighed and transferred into a $100 \mathrm{ml}$ volumetric flask. To this powder, a solution of $50 \mathrm{ml}$ methanol was added and subjected to sonication for around $10 \mathrm{~min}$. The process was continued by making up of the volume using methanol which is later filtered through $0.45 \mu \mathrm{m}$ membrane filter. The filtered solution was further diluted to obtain a concentration of $40 \mu \mathrm{g} / \mathrm{ml}$ by adding $4 \mathrm{ml}$ of the above solution into a $10 \mathrm{ml}$ volumetric flask and the volume was made up using the mobile phase. The response from HPLC was recorded by injecting the solution thrice. The results were interpreted by taking into consideration the parameters such as peak area to concentration and regression equation from calibration graph to derive at the estimated amount of ELB.

\section{Analytical method validation ${ }^{10}$ Linearity}

Linearity study was performed by taking serial dilutions of final concentrations of standard ELB (10, 20, 40, 60, $80,100 \mu \mathrm{g} / \mathrm{ml})$. The solutions were injected into chromatographic system to obtain the chromatograms for each drug concentration in the mobile phase. The graph for linearity was plotted by taking peak area $\mathrm{v} / \mathrm{s}$ concentrations of ELB API $(n=3)$. The regression analysis of ELB was used to deduce correlation coefficient, slope and intercept.

\section{Specificity}

It is the ability of the said method to assess the sample under consideration exclusively without interference from any of the coexisting agents such as impurities, degrading agents and excipients posed from the mobile phase towards the analyte (ELB) under consideration.

\section{Precision}

\section{a) Intraday precision}

In this study intraday precision was carried out within the laboratory and within a day. Six test solutions of $60 \mu \mathrm{g} / \mathrm{ml}$ were injected simultaneously and the peak areas were recorded. Repeatability of the method shows the level of precision exhibited by the method under similar operating conditions during a short span of time. Results of \%RSD of ELB was calculated. 


\section{b) Interday precision}

Interday precision was carried out within the laboratory on three successive days. The same sample preparation was used on different days and different analyst carried out the study. The concentration of the preparation was $60 \mu \mathrm{g} / \mathrm{ml}$ and was injected six test solution at a time on successive days.

\section{Accuracy}

The ICH guidelines clearly state that the recovery studies project the accuracy of the method. Hence, the specified range of recovery was determined by spiking the sample solution at three varying concentrations with preanalyzed API ELB solutions in triplicates.

\section{Limit of detection}

ICH guidelines clearly stated the equation for deriving at the limit of detection as follows:

$$
\mathrm{LOD}=3.3 \times \mathrm{N} / \mathrm{S}
$$

Where $\mathrm{N}=$ Standard deviation of peak areas of the drug and

$\mathrm{S}=$ Slope of calibration curve.

\section{Limit of quantitation}

The calculation of LOQ of sample was followed as per ICH guidelines.

$$
\mathrm{LOQ}=10 \times \mathrm{N} / \mathrm{S}
$$

Where $\mathrm{N}=$ Standard deviation of peak area of the drug and

$\mathrm{S}=$ Slope of the corresponding calibration curve.

\section{Robustness}

The robustness of the current study was determined by altering the parameters of temperature. Sextuplet of the sample solution was prepared $(60 \mu \mathrm{g} / \mathrm{ml})$ and the sample stability was determined by altering the temperatures $\left(25^{\circ} \mathrm{C}\right.$ and $\left.35^{\circ} \mathrm{C}\right)$. The $\%$ RSD was determined to assess the reproducibility of the method.

\section{Stress degradation study}

\section{Acid degradation}

ELB stock solution was diluted by transferring $8 \mathrm{ml}$ into a volumetric flask of $10 \mathrm{ml}$ capacity and the volume was made up to the mark using methanol. $5 \mathrm{ml}$ of this diluted solution was pipetted out into $10 \mathrm{ml}$ volumetric flask and the volume was made up using $1 \mathrm{~N} \mathrm{HCl}$. This solution was subject to sonication for $5 \mathrm{~min}$ and kept aside for $24 \mathrm{hr}$. After $24 \mathrm{hr}, 1 \mathrm{ml}$ was taken and neutralized by using $\mathrm{NaOH}$. A $0.45 \mu \mathrm{m}$ membrane filter was used to filter the solution which was later injected to UFLC for carrying out the analysis.

\section{Alkaline degradation}

ELB stock solution $(8 \mathrm{ml})$ was transferred into a $10 \mathrm{ml}$ volumetric flask and diluted by adding methanol. The solution was sonicated for $15 \mathrm{~min}$ and $5 \mathrm{ml}$ of the above solution was pipetted out and transferred to another 10 $\mathrm{ml}$ volumetric flask and made up the volume with $1 \mathrm{~N}$ $\mathrm{NaOH}$. The solution was again sonicated for 5 min and kept aside for $24 \mathrm{hr} .1 \mathrm{ml}$ of this sample was taken and neutralized by using $\mathrm{HCl}$ and the remaining volume was made up using mobile phase. A $0.45 \mu \mathrm{m}$ membrane filter was used to filter the solution which was later injected to UFLC for carrying out the analysis.

\section{Thermal degradation}

\section{Solid}

Equivalent weight of drug $(10 \mathrm{mg})$ was weighed and kept in Petridish and exposed to a temperature of $60^{\circ} \mathrm{C}$ in hot air oven. The above drug was diluted with methanol to obtain a concentration of $100 \mu \mathrm{g} / \mathrm{ml}$. From this $40 \mu \mathrm{g} / \mathrm{ml}$ solution was prepared with mobile phase and injected. The analysis was also done after $72 \mathrm{hr}$.

\section{RESULTS}

\section{Method optimization}

The optimization of chromatographic parameters was done to carry out the determination of ELB using RP-UFLC in a short analysis time ( $<10 \mathrm{~min})$. Mobile phases of different combinations such as water: acetonitrile, phosphate buffer: acetonitrile and methanol: water and triethylamine were employed in varying ratios at a flow rate of $1 \mathrm{ml} / \mathrm{min}$. The effect of $\mathrm{pH}$ of mobile phase on resolution of ELB was studied. Finally, methanol and water with $0.1 \%$ TEA $(50: 50 \mathrm{v} / \mathrm{v})$ and $\mathrm{pH}$ at 6.4 showed peak with good resolution. The retention time was found $5.51 \mathrm{~min}$ at $240 \mathrm{~nm}$ (Figure 2 and 3).

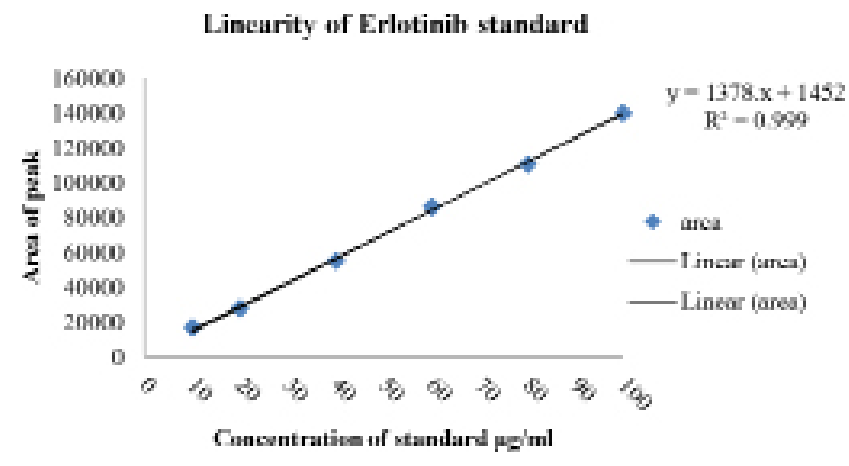

Figure 3: Linearity of Erlotinib Standard. 
In the assay of Erlotinib tablets, the optimized condition was adopted in the subsequent analysis. Method was developed in dosage form and calculated the concentration of drug in dosage form by comparing the peak areas vs concentration of standard. The content of ELB in the tablet was $39.62 \mu \mathrm{g} / \mathrm{ml}$ and the percentage of ELB was $99.80 \%$ (Table 1 and 2 and Figure 4).

\section{Method validation}

The linearity of standard ELB was found in the range of $10-100 \mu \mathrm{g} / \mathrm{ml}$. The response from the detector was found to be linear and correlation coefficient value was found 0.999 and $\mathrm{Y}$ intercept value of 1378. A graph of the calibration curve was shown in Figure 3 and the linearity results were shown in Table 1. In specificity study, therewas noanyinterferencein blank peak, therefore analyte peak was not altered. For intraday precision, the $\%$ RSD was found 0.341 in the morning, 0.302 in the afternoon and 0.182 in the evening for ELB. The \%RSD obtained was less than $2 \%$ which indicates that the proposed method has shown good precision. In an interday precision study, on the first day $\%$ RSD was

Table 1: Linear regression data and system suitability for the analysis of Erlotinib.

\begin{tabular}{|l|c|}
\hline Parameters & Values \\
\hline Retention time $(\mathrm{min})$ & 5.51 \\
\hline Linearity range $(\mu \mathrm{g} / \mathrm{ml})$ & $10-100$ \\
\hline $\mathrm{LOD}(\mu \mathrm{g} / \mathrm{ml})$ & 0.69 \\
\hline $\mathrm{LOQ}(\mu \mathrm{g} / \mathrm{ml})$ & 2.10 \\
\hline Regression data & 1452 \\
\hline Slope & 1378 \\
\hline Intercept & 0.999 \\
\hline Correlation coefficient & 7812 \\
\hline Theoretical plate & 0.70 \\
\hline Tailing factor &
\end{tabular}

\begin{tabular}{|c|c|c|}
\hline \multicolumn{3}{|c|}{ Table 2: Assay results of Erlotinib tablets. } \\
\hline $\begin{array}{c}\text { Actual amount } \\
(\boldsymbol{\mu g} / \mathrm{ml})\end{array}$ & $\begin{array}{c}\text { Amount found } \\
(\mu \mathrm{g} / \mathrm{ml})\end{array}$ & $\% \pm$ Relative error \\
\hline 40 & 39.62 & $99.05 \pm 0.43$ \\
\hline
\end{tabular}

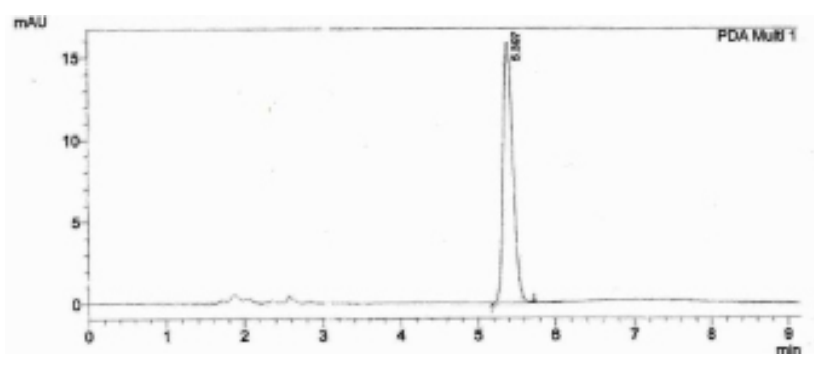

Figure 4: Chromatogram of Erlotinib in dosage form.
0.324 and second and third day was 0.371 and 0.271 , respectively. The $\%$ RSD was found less than $2 \%$ (Table 3 ). Recovery of ELB in dosage form was set as a benchmark in calculating the accuracy. The percentage recovery at each level was in the range of 98.50 to $99.52 \%$ (Table 4). Hence, in the present method accuracy established and was found to be accurate. LOD for ELB was found by the standard deviation of response and slope. In this method LOD was found to be $0.69 \mu \mathrm{g} / \mathrm{ml}$ and LOQ was 2.10 $\mu \mathrm{g} / \mathrm{ml}$ (Table 1). The developed method was observed as robust by changing the temperature and \%RSD was found to be less than 2. The peak area and retention time did not exhibit any marked changes. The tailing factor and retention time parameters were well within the limit. \%RSD of ELB was 0.334 at $25^{\circ} \mathrm{C}$ and 0.257 at $35^{\circ} \mathrm{C}$ (Table 5). The proposed method was superior in comparison to the reported results due to its reduced retention time, high count of theoretical plates and well resolved peaks with the mobile phase composition under consideration. In the stress degradation study, ELB was subjected for acidic, alkaline and thermal degradation. It was stable in thermal condition whereas in acidic and alkaline conditions, negligible degradation was observed. Results of these studies portrayed that no interferences observed in different stress conditions arising due to the presence of excipients, impurities and degraded products. Hence, it was guaranteed that the obtained peak response was generated from a single component only (Figure 5 and 6, Table 6).

\section{DISCUSSION}

Several binary mobile phases were tried to obtain a good peak resolution and $\mathrm{R}_{f}$ value. The mobile phase with a composition of methanol and water $(50: 50 \mathrm{v} / \mathrm{v})$ with TEA $(0.1 \%)$ has shown lower $\mathrm{R}_{f}$ value with high resolution at $240 \mathrm{~nm}$ using a PDA detector. Hence, this condition was adopted for the estimation and validation of ELB in tablet dosage form. The validation method was in accordance with the ICH guidelines. Each of the obtained peak area was plotted against respective concentrations of ELB standard. According to linear regression equation the correlation co-efficient was $0.999\left(r^{2}\right)$. LOD and LOQ were determined by using regression and calibration curve graph values. The LOD and LOQ values are reflected in Table 1.

Intraday precision (repeatability) for the proposed method was assessed by six preparation of analyte in same concentration $(n=3)$ within a day. Similarly, the interday precision and accuracy was studied by adding standard drug and determining the percentage recovery. The developed method has high precision levels as the 


\begin{tabular}{|c|c|c|c|c|c|c|}
\hline \multirow{2}{*}{ Time } & \multirow{2}{*}{$\begin{array}{l}\text { Amount of drug } \\
(\mu \mathrm{g} / \mathrm{ml})\end{array}$} & \multicolumn{2}{|c|}{ Intraday $(n=6)$} & \multirow[t]{2}{*}{ Day } & \multicolumn{2}{|c|}{ Interday precision $(n=6)$} \\
\hline & & $\%$ Precision \pm SD & \%RSD & & $\%$ Precision \pm SD & \%RSL \\
\hline $8.00 \mathrm{am}$ & 60 & $99.53 \pm 0.33$ & 0.341 & $1^{\text {st }}$ day & $99.39 \pm 0.32$ & 0.324 \\
\hline 12.00 noon & 60 & $99.49 \pm 0.30$ & 0.302 & $2^{\text {nd }}$ day & $99.61 \pm 0.42$ & 0.371 \\
\hline $4.00 \mathrm{pm}$ & 60 & $99.26 \pm 0.60$ & 0.182 & $3^{\text {rd }}$ day & $99.78 \pm 0.47$ & 0.271 \\
\hline
\end{tabular}

\begin{tabular}{|c|c|c|c|c|}
\hline \multicolumn{5}{|c|}{ Table 4: Accuracy results. } \\
\hline Amount present $(\boldsymbol{\mu g} / \mathrm{ml})$ & Level of addition $(\%)^{*}$ & Total amount $(\boldsymbol{\mu g} / \mathbf{m l})$ & Amount found $(\boldsymbol{\mu g} / \mathbf{m l})$ & $\%$ Recovery \\
\hline 10 & 80 & 18 & $17.67 \pm 0.23$ & $98.5 \pm 0.72$ \\
\hline 10 & 100 & 20 & $18.95 \pm 1.23$ & $98.68 \pm 0.12$ \\
\hline 10 & 120 & 22 & $21.58 \pm 0.78$ & $99.52 \pm 0.34$ \\
\hline
\end{tabular}

*The accuracy method was repeated in triplicate.

\begin{tabular}{|c|c|c|}
\hline \multicolumn{2}{|c|}{ Table 5: Robustness study results of Erlotinib. } \\
\hline \multirow{2}{*}{} & \multicolumn{2}{|c|}{ Robustness } \\
\cline { 2 - 3 } & $\mathbf{2 5}^{\circ} \mathbf{C}$ & $\mathbf{3 5}^{\circ} \mathbf{C}$ \\
\hline Amount of drug $60(\mu \mathrm{g} / \mathrm{ml})$ & 60 & 60 \\
\hline$\%$ Robustness & $99.53 \pm 0.33$ & $99.78 \pm 0.25$ \\
\hline$\% R S D$ & 0.334 & 0.257 \\
\hline
\end{tabular}

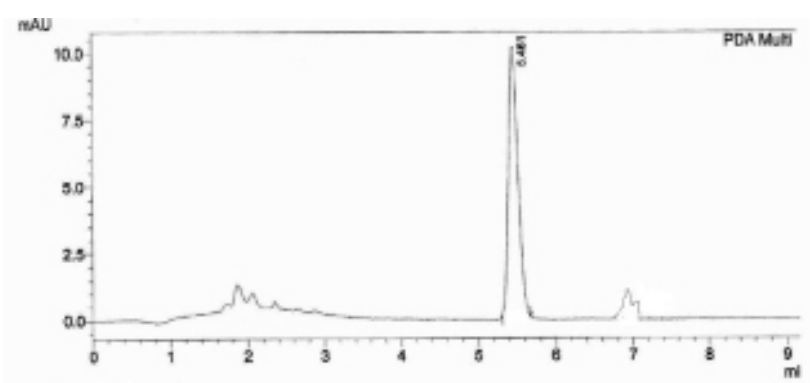

Figure 5: Degradation study of Erlotinib in $1 \mathrm{~N} \mathrm{HCl}$ acid for $24 \mathrm{~h}$.

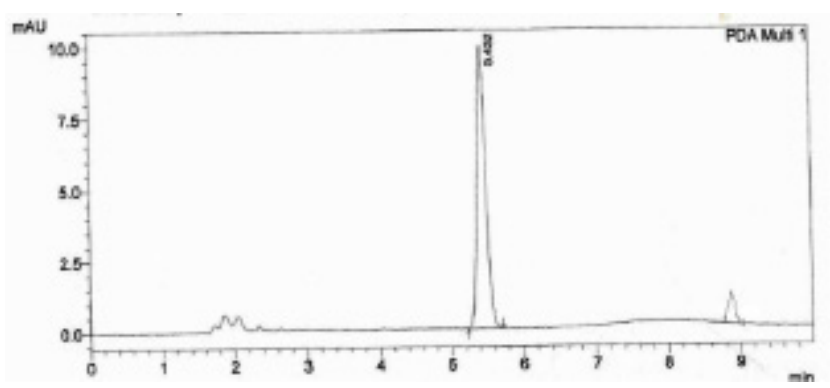

Figure 6: Degradation study of Erlotinib in $1 \mathrm{~N} \mathrm{NaOH}$ base for $24 \mathrm{~h}$.

values of $\%$ RSD have not exceeded $2 \%$. The accuracy of the method was confirmed by considering the recovered concentrations in the developed method. The formulation was also subjected to degradation study under acidic, basic and thermal conditions. The results of the study found no degradation products in thermal
Table 6: Stress degradation study results of Erlotinib.

\begin{tabular}{|c|c|c|c|}
\hline $\begin{array}{c}\text { Stress } \\
\text { conditions }\end{array}$ & Time (h) & $\begin{array}{l}\text { Percentage of } \\
\text { degradation (\%) } \\
( \pm S D, n=3)\end{array}$ & $\begin{array}{c}\text { No. of } \\
\text { degradants }\end{array}$ \\
\hline Acid $(1 \mathrm{~N} \mathrm{HCl})$ & 24 & $4.25 \pm 0.5$ & 1 \\
\hline $\begin{array}{c}\text { Alkaline } \\
(1 \mathrm{~N} \mathrm{NaOH})\end{array}$ & 24 & $8.11 \pm 0.12$ & 1 \\
\hline $\begin{array}{l}\text { Thermal } \\
\text { 1) Solid } \\
\text { 2) Liquid }\end{array}$ & $\begin{array}{l}72 \\
72\end{array}$ & $\begin{array}{l}\text { Stable } \\
\text { Stable }\end{array}$ & $\begin{array}{l}-- \\
--\end{array}$ \\
\hline
\end{tabular}

condition, whereas in acidic and basic conditions small percentage of degradation was observed. The developed formulation was stable in thermal conditions for three days. The results suggested that the developed RP-UFLC method can be applied for the screening of various formulations of ELB.

\section{CONCLUSION}

It is concluded that the analytical method developed for ELB was found to be simple, precise, robust and economical. The validated method shows good quality and drug contents are in concordance with label claims of the tablet dosage form. Hence, the analytical method developed for ELB can be extensively used in labs for quality control purposes.

\section{ACKNOWLEDGEMENT}

We would like to thank Principal SAC College of Pharmacy, B.G. Nagara, India, for providing laboratory resources and for their help during the analytical studies.

\section{CONFLICT OF INTEREST}

The authors declare no conflict of interest. 


\section{ABBREVIATIONS}

ELB: Erlotinib; TEA: Triethylamine; RP-UFLC: Reverse phase-ultrafast liquid chromatography; EGFR: Epidermal growth factor receptors; LOQ: Limit of quantification; LOD: Limit of detection; ICH: International Conference on Harmonisation.

\section{REFERENCES}

1. Kobayashi K, Hagiwara K. Epidermal growth factor receptor (EGFR) mutation and personalized therapy in advanced nonsmall cell lung cancer (NSCLC). Target Oncol. 2013;8(1):27-33. doi: 10.1007/s11523-013-0258-9.

2. Latha ST, Ananda TS, Jambulingam M, Sereya K, Kamalakannan D, Anilkumar M. Development and validation of RP-HPLC method for the estimation of ELB in pharmaceutical formulation. Arab J Chem. 2017;10:S1138-44.

3. Saravanan VS, Bojja MR. Analytical method development and validation for the determination of ELB hydrochloride bulk and in pharmaceutical dosage form. J Drug Deliv Ther. 2013;3(1):50-4

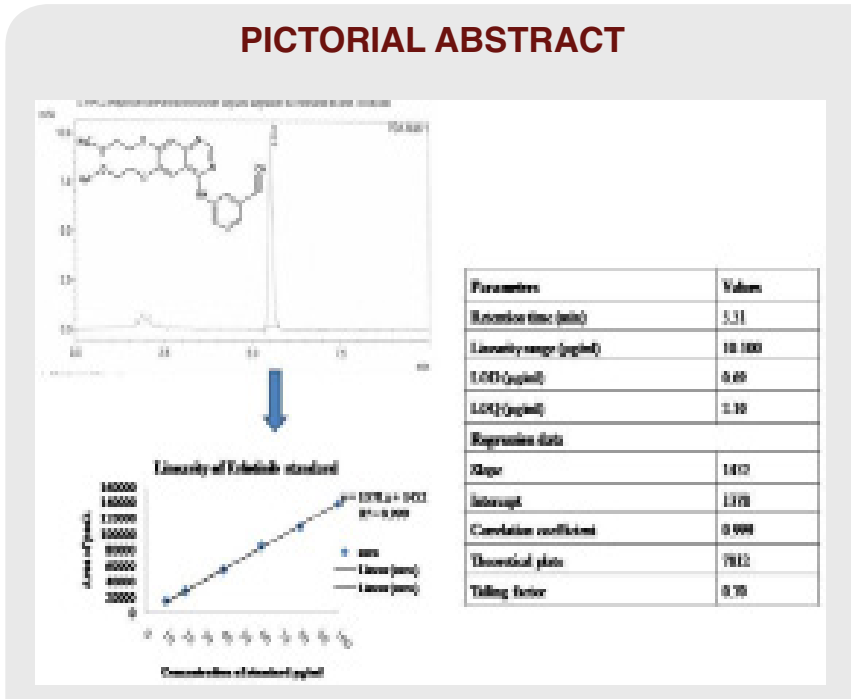

4. Kalyana CV, Gowri SD. Development and validation of RP-HPLC method for estimation of ELB in bulk and its pharmaceutical formulation. Rasa J Chem. 2011;4:393-9.

5. Ravi KK, Sankara BK, Nagabhushanam CH. A validated LC method for the estimation of ELB hydrochloride in bulk and tablet dosage form. Int $\mathrm{J}$ Pharm Biomed Res. 2013;4(1):1-4.

6. Naveen KR, Rajendra PVVS, Maharana PK. Development and validation of a stability indicating UPLC method for determination of ELB in pharmaceutical formulations. Der Pharm Chem. 2012;4(1):2288-97.

7. Amjad A, Mohammad I, Mufassir MSK, Firoz K. Analytical method development and validation of ELB hydrochloride in bulk and pharmaceutical dosage form by RP-HPLC. J Innov Appl Pharm Sci. 2018;3(3):1-6.

8. Soheila B, Adeleh D, Hadi V, Arash K, Parvin ZM. Development and application of an HPLC method for ELB protein binding studies. Adv Pharma Bullet. 2013;3(2):289-93.

9. Erin R, Lepper SM, Swain AR, Tan WD, Figg AS. Liquid-chromatographic determination of ELB (osi-774), an epidermal growth factor receptor tyrosine kinase inhibitor. J Chromatogr B. 2003;796(1):181-8.

10. International Conference on Harmonisation $(\mathrm{ICH})$, validation of analytical procedures: text and methodology, Q2(R1), Geneva, Switzerland; 2005.

\section{SUMMARY}

The analytical conditions developed were in good resolution and short duration analysis. The \%RSD of the various parameters under consideration was found to be well within the limits. In the degradation study, very few or no degraded products were observed which indicates that the formulation was stable in acidic, basic conditions and in the presence of heat.

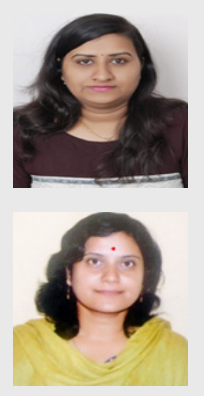

\section{About Authors}

Ms. Purvini K, Department of Pharmaceutical Analysis, Sri Adichunchanagiri College of Pharmacy, B.G. Nagara Mandya, Karnataka, India. Research interest is development of analytical method for novel drugs, degradation and stability studies of novel drugs by using HPLC and RP-UFLC.

Dr. Jaishree Vaijanathappa, Department of Pharmaceutical Chemistry, JSS College of Pharmacy, JSS Academy of Higher Education and Research, Mysuru-570015, Karnataka, India. Research interest is on Herbal drug development, Analytical Method Development, Isolation of phytoconstituents, screening of isolated compounds for Antioxidant, Antibacterial, Hepatoprotective and Antidiabetic properties.

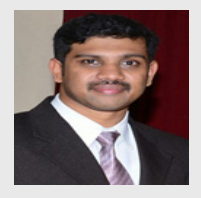

Mr. Chethan I. A., Department of Pharmaceutical Chemistry, JSS College of Pharmacy, JSS Academy of Higher Education and Research, Mysuru-570015, Karnataka, India. Research interest is on Isolation of phytoconstituents, screening of isolated compounds for Antioxidant, Antibacterial, Hepatoprotective and Antidiabetic properties.

Cite this article: Purvini K, Chethan IA, Jaishree V. Novel Analytical Method Development, Validation and Stability Study of Anticancer Drug Erlotinib in Tablet Dosage Form by RP-UFLC. Indian J of Pharmaceutical Education and Research. 2021;55(2s):s589-s594. 